\title{
MISMATCHING CONVERTIBLE DEBENTURES AND COMMON STOCK UNDER SECTION 16(b)
}

\section{INTRODUCTION}

Section 16(b) of the Securities Exchange Act of $1934^{1}$ was intended ${ }^{2}$ to deter insiders ${ }^{3}$ from using iuformation not available to the investing public in order to earn "short swing" profits. ${ }^{4}$ The statute was designed to be read literally and applied mechanically, so that its scope would be understood and its application predictable. ${ }^{5}$ Unfortunately, application of the statute to business transactions often produces inconsistent results that do not serve the purposes of the statute. ${ }^{6}$

1. 15 U.S.C. $\$ 78 \mathrm{p}(\mathrm{b})$ (1982).

2. See infra note 5 .

3. Section 16(a), 15 U.S.C $\S 78 \mathrm{p}(\mathrm{a})$ (1982), provides that officers, directors, and $10 \%$ beneficial owners of an issuer are "insiders" and subject to 16(b), as well as to 16(a) reporting requirements.

4. "Short-swing" profits are profits resulting from purchases and sales of the issuer's equity securities occurring within a six month period. See infra note 17 and accompanying text.

5. Senate Reports demonstrate that curtailing improper speculative use of information available to insiders and not to the investing public was the primary concern of section 16(b). See S. REP. No. 1455, 73d Cong., 2d Sess. 68 (1934). The legislative history demonstrates that Congress recognized past abuses both by major stockholders and by officers and directors of the corporation:

Among the most vicious practices unearthed . . . was the flagrant betrayal of their fiduciary duties by directors and officers of the corporations who used their positions of trust and the confidential information which came to them in such positions, to aid them in their market activities. Closely allied to this type of abuse was the unscrupulous employment of inside information by large stockholders who, while not directors and officers, exercised sufficient control over the destinies of their companies to enable them to acquire and profit by information not available to others.

Id. at 68. See also S. ReP. No. 792, 73d Cong. 2d Sess. 9 (1934).

The most important witness to appear at the Senate Committee on Banking and Currency hearing concerning section 16 (then proposed section 15), was Thomas G. Corcoran, a drafter of section 16, from the office of the Counsel for the Reconstruction Finanec Corporation. According to Corcoran, the objective of the short-swing profit provision is:

[t]o prevent directors receiving the benefits of short-term speculative swings on the securities of their own companies, because of inside information. The profit on such transaction under the bill would go to the corporation. You hold the director, irrespective of any intention or expectation to sell the security within 6 months after, because it will be absolutely impossible to prove the existence of such intention or expectation, and you have to have this crude rule of thumb, because you cannot undertake the burden of having to prove that the director intended, at the time he bought, to get out on a short swing.

Hearings on Stock Exchange Practices Before the Senate Comm. on Banking and Currency on S. Res. 84, 73d Cong., Ist Sess. 6557 (1934). For further excerpts from Senate hearings concerning section 16(b), see generally Note, Exceptions to Liability Under Section 16(b): A Systematic Approach, 87 YALE L.J. 1430, 1430-31 (1978) [hereinafter cited as Note, Exceptions to Liability Under Section 16(b)]. See infra notes 16-21 and accompanying text.

6. See infra notes 22-44 and accompanying text (conversion transactions); notes $65-75$ and accompanying text (hostile tender offers); notes 89-114 and accompanying text (transactions involv- 
Recently, in Gund v. First Florida Banks, ${ }^{7}$ the United States Court of Appeals for the Eleventh Circuit held that an insider violated 16(b) when he sold his convertible debentures and purchased common stock, ${ }^{8}$ even though the market prices of the two securities fluctuated independently.9 The Eleventh Circuit mechanically applied the statute to the Gund transaction and forced the insider to disgorge his profits. ${ }^{10}$ Gund is a typical example of decisions where 16(b) has been applied even though the economics of the transactions preclude any possibility of speculative abuse. ${ }^{11}$,

This note begins by examining judicially imposed limitations on the scope of $16(\mathrm{~b})$, and demonstrates that $16(\mathrm{~b})$ does not always operate simply and effectively. ${ }^{12}$ In reality, courts have interpreted the provision in light of the complex financial transactions in which issues of $16(\mathrm{~b})$ liability arise. The note then argues that the Gund transaction presented no opportunity for speculative abuse and that the Eleventh Circuit reached an incorrect result when it found the insider liable for $16(\mathrm{~b})$ profits. ${ }^{13}$ The note suggests that purchases and sales of convertible debt securities and underlying stock should be matched for 16(b) purposes only when the market prices of the two classes of securities fluctuate according to their conversion ratio. ${ }^{14}$ Conversely, the note suggests that where the two classes of securities are traded independently, as in Gund, the rationale for treating convertible debentures as equity securities within the meaning of the short-swing profit provision does not apply. ${ }^{15}$ In this environinent, purchases and sales of the two classes of securities should not be matched to form $16(\mathrm{~b})$ profits.

ing sale of convertible debentures and purchases of common stock); note 116 (transaction involving sale of warrants and purchase of common stock).

7. 726 F.2d 682 (11th Cir. 1984).

8. Id. at 687 .

9. Id. at 684 .

10. Id. Gund is discussed infra notes 89-114 and accompanying text.

11. See, e.g., Texas Int'l Airlines v. National Airlines, 714 F.2d 533 (5th Cir. 1983) (failed hostile tender offeror held liable for 16(b) profits where it sold securities for cash prior to merger of target with third party), cert. denied, 465 U.S. 1052 (1984) (discussed infra notes 67-75 and accompanying text); Park \& Tilford, Inc. v. Shulte, 160 F.2d 984 (2d Cir.) (conversion of convertible securities treated as 16(b) purchase), cert. denied, 332 U.S. 761 (1947) (discussed infra notes 16-18 and accompanying text).

12. See infra notes 16-86 and accompanying text.

13. See infra notes 87-114 and accompanying text.

14. See infra notes 103-09 and accompanying text.

15. See infra notes 110-12 and accompanying text. 


\section{The Scope of Section 16(b): The Illusory Bright Line}

\section{A. The Early Objective Approach: Convertible Securities.}

Section $16(b)$ allows an issuer or shareholder to recover profits earned by "insiders" on a purchase and sale, or sale and purchase, of the issuer's equity securities, ${ }^{16}$ taking place within a six month period. ${ }^{17}$ The provision was intended by its drafter to be mechanically applied to deter speculative abuse of inside information. ${ }^{18}$ The drafter felt that "insiders could exploit information not generally available to others to secure quick profits." 19 Congress feared that such trading might endanger the Securities Exchange Act's goal of insuring "fair and honest markets."20 As the Supreme Court has stated, "the only method Congress deemed effective to curb the evils of insider trading was a 'flat rule' taking the profits out of a class of transactions in which the possibility of abuse was believed to be intolerably great." 21

16. "Equity security" is defined to include "any stock or similar security; or any security convertible, with or without consideration into such a security, or carrying any warrant or right . . . ." 15 U.S.C. $\$ 76 \mathrm{c}(\mathrm{a})(11)$ (1982) (emphasis added).

17. Section $16(\mathrm{~b})$ reads as follows:

For the purpose of preventing the unfair use of information which may have been obtained by such beneficial owner, director, or officer by reason of his relationship to the issuer, any profit realized by him from any purchase and sale, or any sale and purchase, of any equity security of such issuer (other than an exempted security) within any period of less than six months, ... shall inure to and be recoverable by the issuer, irrespective of any intention on the part of such beneficial owner, director, or officer in entering into such transaction. . . . Suit to recover such profit may be instituted at law or in equity . . . by the issuer, or by the owner of any security of the issuer in the name and in the behalf of the issuer if the issuer shall fail or refuse to bring such suit within sixty days after request or shall fail diligently to prosecute the same thereafter. . . . This subsection shall not be construed to cover any transaction where such beneficial owner was not such both at the time of the purchase and sale, or the sale and purchase, of the security involved, or any transaction or transactions which the Commission by rules and regulations may exempt as not comprehended within the purpose of this subsection.

15 U.S.C. $\S 78 \mathrm{p}(\mathrm{b})(1982)$.

18. See supra note 5 .

The provision's intended objective approach is expressed clearly in its language: "irrespective of any intention on the part" of the insider. Where the conditions of section $16(b)$ are met, the insiders must disgorge profits from the transactions. See also Note, Corporations-Securities Exchange Act of 1934-Partial Avoidance of Section 16(b) Liability Through Use of the Split Sale Device, 47 TUL. L. REv. 1191, 1195 (1973) (noting that although 16(b) was not intended to act as a "general anti-fraud" provision, it was designed to "absolutely prohibit certain transactions," regardless of the actual intent of the insider).

19. Kern County Land Co. v. Occidental Petroleum Corp., 411 U.S. 582, 592 (1973) (citing S. REP. No. 1455, 73d Cong., 2d Sess. 55 (1934) and S. Rep. No. 792, 73d Cong., 2d Sess. 9 (1934), both of which noted the widespread abuses of information and betrayal of fiduciary obligations among insiders).

20. 15 U.S.C. $\S 78 p(b)(1982)$.

21. Reliance Elec. Co. v. Emerson Elec. Co., 404 U.S. 418, 422 (1972); see also Smolowe v. Delendo Corp., 136 F.2d 231, 235 (2d Cir.) ("It is apparent . . . from the language of section 16(b) itself, as well as from Congressional hearings, that the only remedy which its framers deemed effec- 
Park \& Tilford, Inc. v. Shulte, 22 decided by the United States Court of Appeals for the Second Circuit in 1947, is representative of the early, mechanical applications of section 16(b). Park \& Tilford involved an insider's conversion of preferred stock into common stock, and subsequent sale of the common stock within six months of the conversion. The court treated the conversion as a " $16(\mathrm{~b})$ purchase" of common stock and matched it with the subsequent sale of common stock. ${ }^{23}$ Where this "objective"24 approach is taken, a plaintiff suing to recover profits need show only the insider status of the defendant, the purchase and sale of the corporation's equity securities within six months, and the profit made from the transaction. The plaintiff need not show that the transaction provided an opportunity for speculative abuse of inside information..$^{25}$

Objective application of this statute to conversion transactions produced disappointing results, however, and in two later cases, Blau v. Max Factor \& Co. ${ }^{26}$ and Blau v. Lamb, ${ }^{27}$ courts declined to treat a conversion of convertible securities as a purchase of the underlying securities for section 16 (b) purposes. ${ }^{28}$

In 1947, Max Factor, a family-owned corporation, conducted a pub-

tive for this reform was the imposition of a liability based on an objective measure of proof."), cert. denied, 320 U.S. 751 (1943).

22. 160 F.2d 984 (2d Cir.), cert. denied, 332 U.S. 761 (1947).

23. Id. at $987-88$.

24. "Objective" application of section 16(b) refers to a literal, mechanical application of the statute. See, e.g., Tomlinson, Section 16(b): A Single Analysis of Purchases and Sales-Merging the Objective and Pragmatic Analyses, 1981 DUKE L.J. 941, 944-47 ("This approach requires only a factual inquiry: has a transfer for value occurred?").

Other cases applying an objective analysis include: Heli-Coil Corp. v. Webster, 352 F.2d 156 (3d Cir. 1965) (conversion of convertible debentures into common stock held a 16(b) sale); Smolowe v. Delendo, 136 F.2d 231 (2d Cir. 1943) (not necessary that shares sold within six months actually be the same shares purchased within the six month period; sales and purchases during the time period will be matched so that defendant disgorges the highest profit possible).

25. See Tomlinson, supra note 24, at 944 (objective analysis described); see also Wentz, Refining a Crude Rule: The Pragmatic Approach to Section 16(b) of the Securities Exchange Act of 1934, 70 Nw. U.L. REv. 221, 227-28 (1975) ("A court applying the objective approach as formulated in Smolowe and Park \& Tilford, and recognizing that Congress intended section 16(b) to control market manipulation and insider trading, will construe the statute broadly in order to restrict and deter such activity." (footnote omitted)).

26. 342 F.2d 304 (9th Cir.), cert. denied, 382 U.S. 892 (1965).

27. 363 F.2d 507 (2d Cir. 1966), cert. denied, 385 U.S. 1002 (1967).

28. Id. at 522; Max Factor, 342 F.2d at 309.

Other cases in which courts have rejected objective analysis on the facts and have instead explored the potential for speculative abuse include: Petteys v. Butler, 367 F.2d 528, 537 (8th Cir. 1966) (conversion of convertible preferred stock into common stock held not a section 16(b) sale), cert. denied, 385 U.S. 1006 (1967); Ferraiolo v. Newman, 259 F.2d 342, 346 (6th Cir. 1958) (facts similar to Petteys), cert. denied, 359 U.S. 927 (1959); Blau v. Mission Corp., 212 F.2d 77, 80 (2d Cir.) (transfer of securities between parent company and wholly owned subsidiary held not a section 16(b) sale), cert. denied, 347 U.S. 1016 (1954). 
lic offering of common stock. ${ }^{29}$ The corporation offered class A securities to the public the following year. ${ }^{30}$ The common stock was convertible into the class A securities. Because the class A paid a higher dividend than the common, a majority of the public shareholders converted their common into class A. ${ }^{31}$ The "family insiders" continued to hold the common stock, which paid less in dividends, thus "retaining earnings . . . otherwise payable to family stockholders, for use in the business, without exposing the family stockholders to potential tax liability." 32 The class A stock "had equal voting rights with the common, rights on liquidation were the same, neither class was subject to redemption, and both were fully transferrable." 33

In 1960, the family stockholders "decided to offer a portion of their stock interest to the public." 34 The family converted their common stock to class A stock prior to conducting a public offering of the class A stock. $^{35}$ The United States Court of Appeals for the Ninth Circuit held that the conversion was not a purchase of the class A stock that could be matched with the public sale of the class A stock for the purposes of section $16(b) .{ }^{36}$ The court pointed out that:

[t]he exchange . . . did not interrupt the continuity of [the insiders'] investment: it did not increase or decrease the amount invested, or alter in any way the risk assumed long years before. Moreover, since there was no speculative advantage in holding class $A$ rather than Common, the exchange conferred no opportunity for speculative profit which [the insiders] did not already enjoy. ${ }^{37}$

Though also declining to treat the conversion as a "purchase" for 16(b) purposes, the Second Circuit in Lamb developed a different analysis than employed in Max Factor, emphasizing the "economic equivalence of convertible and underlymg securities." 38 In Lamb, the plaintiff sought to match a conversion of convertible preferred stock into common stock with a later sale of the common stock, much like the transaction at issue in Park \& Tilford. ${ }^{39}$ The Lamb court held that liability should not attach:
29. Max Factor, 342 F.2d at 306.
30. Id.
31. Id.
32. Id.
33. Id.
34. Id.
35. Id.
36. Id. at 309.
37. Id. at 308.
38. Lamb, 363 F.2d at 521-23.
39. See supra note 23 and accompanying text. 
[I]n general, the purchase by an insider of his issuer's equity securities, followed in less than six months by their conversion, cannot facilitate short swing trading for speculative profits in the convertible securities because market activity, including arbitrage trading, will insure that the convertible securities have a market price at least equivalent to the aggregate price of the securities into which they are convertible ... 40

Because the convertible preferred and common stock were "economically equivalent"- - that is, because the two classes of securities traded at their conversion ratio-conversion from one to the other would not affect the insiders' ownership position or their opportunity to profit from inside information. ${ }^{41}$

The Lamb court argued that in deciding "whether a certain transaction is a section 16(b) 'purchase' or 'sale' it is relevant to first consider whether the transaction in any way makes possible the unfair insider trading that section 16(b) was designed to prevent."42 The court's language indicated that this threshold inquiry should be made with respect to all types of transactions subject to section $16(\mathrm{~b}) .43$ In essence, the courts in Max Factor and Lamb looked beyond the straightforward mechanical requirements of the statute to the econoinics of conversion transactions. Because, in Max Factor, the continuity of the insiders' investments was not substantially altered by the conversion, and because, in $L a m b$, the convertible and underlying securities were economically equivalent, the courts in those cases declined to impose $16(\mathrm{~b})$ liability. ${ }^{44}$

40. Lamb, 363 F.2d at 521; cf. American Standard, Inc. v. Crane Co., 346 F. Supp. 1153, 1161 (S.D.N.Y. 1971) (doctrine of economic equivalence applies only where securities involved are both from same issuer), rev'd on other grounds, 510 F.2d 1043 (2d Cir. 1974), cert. denied, 421 U.S. 1000 (1975).

41. See 3B H. Bloomenthal, Securities and Federal Corporate Law $\$ 10.08$ (Rev. 1985); see also Ferraiolo v. Newman, 259 F.2d 342, 345-46 (6th Cir. 1958) (securities were economically equivalent because conversion of convertible preferred into common stock "worked no material change in [the insider's] proportional equity ownership"), cert. denied, 359 U.S. 927 (1959).

42. Lamb, 363 F.2d at 518 .

43. The view that section 16 (b) liability should not attach to transactions that provide no opportunity for speculative abuse remains the law in the Second Circuit. See, e.g., infra note 109 and accompanying text; see also Heublein, Inc. v. General Cinema Corp., 559 F. Supp. 692, 704 (S.D.N.Y.) (where inside information is immaterial, thus eliminating any possibility of speculative abuse, 16(b) liability does not attach), affd, 722 F.2d 29 (2d Cir. 1983), cert. denied, 465 U.S. 1066 (1984) (discussed infra note 109); Newmark v. RKO General, Inc., 425 F.2d 348, 351 n.2 (2d Cir.), cert. denied, 400 U.S. 854 (1970) (rejecting the objective approach "in favor of the more 'pragmatic' approach of applying the statute only to those situations subject to speculative manipulations").

44. For further discussion of these two cases, see infra notes 103-07 and accompanying text.

The SEC codified the holdings of Max Factor and Lamb in Rule 16b-9(a), 17 C.F.R. $\$ 240.16 \mathrm{~b}$ 9(a) (1985):

(a) Any acquisition or disposition of an equity security involved in the conversion of an equity security which, by its terms or pursuant to the terms of the corporate charter or other governing instruments, is convertible immediately or after a stated period of time into another equity security of the same issuer, shall be exempt from the operation of 


\section{B. The Pragmatic Approach: Kern County Land Co. v. Occidental Petroleum Corp.}

The Max Factor and Lamb cases form the backdrop to the most important case to date in determining the scope of section 16(b): Kern County Land Co. v. Occidental Petroleum Corp. 45 In Kern County, the Court adopted a "pragmatic" approach to the short-swing profit provision as applied to hostile takeovers, mergers, and corporate reorganizations. ${ }^{46}$ A brief review of Kern County and its progeny demonstrates that $16(b)$ is not the simple but effective deterrent to short-swing insider trading intended by the provision's drafters. Instead, this review will show that 16 (b) has been continually reinterpreted by the courts in an attempt to bring it in conformity with economic reality. ${ }^{47}$

Rather than subject the transaction in question to an "objective" analysis, the Supreme Court in Kern County apphed a two-step analysis to determine whether the insider violated section 16(b). The Court first asked whether the transaction was "unorthodox" and therefore deserving of more careful scrutiny than that afforded by literal application of the statute. ${ }^{48}$ Having determined that the transaction was "unortho-

section 16(b) of the Act: Provided, however, That this rule shall not apply to the extent that there shall have been either (1) a purchase of any equity security of the class convertible (including any acquisition of or change in a conversion privilege) and a sale of any equity security of the class issuable upon conversion, or (2) a sale of any equity security of the class convertible and any purchase of any equity security issuable upon conversion (otherwise than in a transaction involved in such conversion or in a transaction exempted by any other rule under section 16(b)) within a period of less than 6 months which includes the date of conversion.

This rule provides a safe harbor for conversion transactions by stating that conversions will not be considered purchases or sales for the purposes of section 16(b). However, the rule provides that the safe harbor is not available where the purchase or sale of the convertible security and purchase or sale of the underlying security occur within a six month period including the conversion. Also, Rule 16b-9(a) does not incorporate an economic equivalency test. See infra note 108. In other words, there is no requirement that the convertible and underlying securities trade in relation to one another. The rule, like $16(\mathrm{~b})$ itself, was intended to be applied mechanically.

45. 411 U.S. 582 (1973).

46. See generally L. LOSS, Fundamentals of SECuRITIES REgulation 612-30 (1983) (reprinting and discussing Kern County); Note, Insider Liability for Short-Swing Profits: The Substance and Function of the Pragmatic Approach, 72 Mich. L. REv. 592, 594-95 (1974) (discussing Kern County's "possiblity of abuse test").

47. See Note, Exceptions to Liability Under Section 16(b), supra note 5, at 1432-33 (noting that "courts have repeatedly fashioned ad hoc exemptions from the statute in circumstances appearing to afford little opportunity for speculative abuse").

48. Kern County, 411 U.S. at 593-96. The Court referred to Professor Loss for the proposition that the term "unorthodox" transactions refers to transactions involving "stock conversions, exchanges pursuant to mergers and other corporate reorganizations, stock reclassifications, and dealings in options, rights and warrants." Id. at 594 n.24 (citing L. LOSS, SECURITIES REgulation 1069 (2d ed. 1961)).

"Unorthodox" transactions are those that do not easily fit within the framework of the statute. One commentator has noted that the "garden-variety type of situation section 16(b) was intended to cover is readily identifiable and the right to recover in this situation is generally clear." $3 \mathrm{~B} H$. 
dox," the Court then addressed the question of whether the transaction presented an opportunity for speculative abuse. ${ }^{49}$

Kern County arose from Occidental Petroleum's unsuccessful takeover attempt of Old Kern, the "target company."50 During the takeover attempt, Occidental acquired over ten percent of Old Kern equity securities, making Occidental a statutory insider of Old Kern. ${ }^{51}$ In response to the takeover attempt, Old Kern arranged a defensive merger with its "white knight," Tenneco. ${ }^{52}$ As part of the merger agreement between Old Kern and Tenneco, Tenneco agreed to exchange its own securities for outstanding Old Kern securities. ${ }^{53}$ Thus, Occidental exchanged its Old Kern securities for Tenneco securities at a sizeable profit. Examining the transactions, the Supreme Court held that an exchange of securities pursuant to a merger was not automatically a "16(b) sale." Instead, the Court labelled the transaction "unorthodox." 54 It then proceeded to inquire whether the transaction presented an opportunity for speculative abuse. 55

The Court concluded that section 16(b) had not been violated, due to the "involuntary nature of Occidental's . . . exchange coupled with the absence of the possibility of speculative abuse of insider trading." 56 The Court noted that "after all, Occidental was a tender offeror, threatening to seize control of Old Kern, displace its management, and use the company for its own ends." 57 Thus, "the possibility that Occidental had, or had the opportunity to have, any confidential information . . . seems

BLOOMENTHAL, supra note 41, at $\S 10.01[4]$. The scope of section $16(\mathrm{~b})$ and the right to recover is often unclear in transactions involving options, warrants, convertible securities, and exchanges pursuant to mergers.

49. Kern County, 411 U.S. at 582, 593-95.

50. Id. at $584-91$.

51. Id. at 585 .

52. Id. at 585-86. "White knight" has become a common term in the language of corporate lawyers and executives. A white knight is a company invited by the target corporation to defeat the hostile tender offer by making a separate bid. See, e.g., Data Probe Acquisition Corp. v. Datalab, Inc., 568 F. Supp. 1538, 1552 (S.D.N.Y.), rev'd, 722 F.2d 1 (2d Cir. 1983), cert. denicd, 465 U.S. 1052 (1984).

53. Id. at 586 .

54. Id. at 593-94.

55. Id. at 596-99. The Court stated:

Several decisions have been read as to apply a so-called "objective" test in interpreting and applying $\S 16(\mathrm{~b})$. . . . Under some broad language in those decisions, $\S 16(\mathrm{~b})$ is said to be applicable whether or not the transaction in question could possibly lend itself to the types of speculative abuse that the statute was designed to prevent. By far the greater weight of authority is to the effect that a "pragmatic" approach to $\S 16(b)$ will best serve statutory goals.

Id. at 594 n.26.

56. Id. at 600 .

57. Id. at 598. 
remote."58 The Court considered the transaction involuntary because the defensive merger was arranged by Old Kern. The Court stated that if Occidental had sold its Old Kern securities for cash prior to the exchange, it would clearly have violated $16(\mathrm{~b}) .59$

The Supreme Court did not entirely do away with the objective approach to section 16(b) with its decision in Kern County. Courts continue to apply the provision objectively to garden variety transactions, and earlier "objective" approach decisions that do not involve "unorthodox" transactions remain good law. ${ }^{60}$ For example, an insider may reduce or entirely avoid section 16 (b) liability by "splitting" his sales, thus eliminating statutory insider status on the first sale. ${ }^{61}$ Similarly, an insider may avoid liability by selling securities six months and one day after his purchase. ${ }^{62}$ However, predicting how section $16(\mathrm{~b})$ will operate even in these instances is sometimes difficult. Insiders have been trapped

58. Id.

59. Kern County, 411 U.S. at 599-600. Texas Int'l Airlines v. National Airlines, 714 F.2d 533 (5th Cir. 1983), cert. denied, 465 U.S. 1052 (1984), discussed infra notes 67-84 and accompanying text, involved just such a transaction. The unsuccessful tender offeror sold securities of the target corporation prior to a merger and exchange of securities. Id. at 535. The Fifth Circuit followed the dicta in Kern County and held the insider liable under section 16(b). Id. at 593-40.

60. For a discussion of transactions entitled to pragmatic analysis, see Tomlinson, supra note 24 , at 949.

61. See Reliance Elec. Co. v. Emerson Elec. Co., 404 U.S. 418 (1972). In Reliance, the defendant, a $10 \%$ beneficial owner, engaged in a two step sale of the target company's securities, after a failed takeover attempt. The insider engaged in its transactions before the Kern County decision. It therefore sold its securities prior to an exchange of securities with the surviving corporation apparently because it believed that an exchange of securities pursuant to the defensive merger would be considered a section 16(b) sale. In order to reduce the section 16(b) profits that would have resulted from matching the sales with the purchases made less than six months earlier, the insider first reduced ownership to slightly below $10 \%$ by selling shares to one purchaser, then sold the remaining securities to another purchaser. Id. at 420-21. The Supreme Court construed the statute strictly, and matched only the first sale and the purchases that originally took the insider over the $10 \%$ mark. Id. at 423-25. Section 16(b) provides that "this subsection shall not be construed to cover any transactions where such beneficial owner was not such both at the time of purchase and sale . . . ." 15 U.S.C. $\S 78 \mathrm{p}(\mathrm{b})$ (1982). The insider thus "split" his sales of the issuer's equity securities: with the first sale bringing the insider to less than $10 \%$ ownership, and thereby placing the second sale-of the remainder of the insider's holdings-outside the purview of section 16(b) liability. The Reliance Court stated:

To be sure, where alternative constructions of the terms of section 16(b) are possible, those terms are to be given the construction that best serves the congressional purpose of curbing short-swing speculation by corporate insiders. But a construction of the term "at the time ... of sale" that treats two sales as one upon proof of a pre-existing intent by the seller is scarcely in harmony with the congressional design of predicating liability upon an "objective measure of proof."

Id. at 424-25 (quoting Smolowe v. Delendo Corp., 136 F.2d 231, 235 (2d Cir. 1943), cert. denied, 320 U.S. 751 (1943)). See Comment, Section 16(b), Measuring Profits Realized in Option Transactions, 1983 ARIz. ST. L.J. 855, 859-61 (discussing the Reliance two step split sale technique).

62. See Comment, supra note 61, at $859-61$ (discussing "six months and a day" technique, as well as other methods that allow insiders to structure transactions to avoid section 16(b) profits). 
when relying on such strategies. ${ }^{63}$

Though intended to illuminate proper application of section $16(\mathrm{~b})$ in the context of unorthodox transactions, Kern County does not provide a bright line for determining which unusual transactions will produce 16(b) profits. Even after Kern County, insiders engaging in transactions that do not present an opportunity for speculative abuse remain subject to section $16(\mathrm{~b})$ liability.

\section{The Shifting Border Between the Objective and Pragmatic Analyses: Texas International Airlines v. National Airlines and Pay Less Drug Stores v. Jewel Companies, Inc.}

Max Factor and Lamb eliminated 16(b) liability from conversion transactions that present no opportunity for speculative abuse. Similarly, Kern County removed "unorthodox" transactions from the scope of the statute where the purpose of preventing short-swing trading by insiders is not served. These decisions eliminate any pretense that $16(\mathrm{~b})$ is a "flat rule," easily understood and enforced. In the years since Kern County, constant litigation has defined and redefined the boundaries of section 16(b). ${ }^{64}$ Two such recent cases are Texas International Airlines $v$.

63. See Reece Corp. v. Walco Nat'1 Corp., 565 F. Supp. 158, 162-63 (S.D.N.Y. 1981). In Reece, although the insider engaged in more that one sale, "there was a single plan of disposition negotiated [by the insider] with the same buyer. . . ." Id. at 162. Thus, the court determined that "from any standpoint of reality and substance, there was a single sale. The attempt to divide it into two sales was wholly artificial and contrived." Id. In this instance, both sales were matched to earlier purchases to arrive at section $16(\mathrm{~b})$ profits. For a discussion of Reece, see Block \& Barton, Section 16(b) of the Exchange Act: An Archaic Insider Trading Statute in Need of Reform, 12 SEC. REG. L.J. 203, 216 (1984) (examining Reliance and Reece as part of a more general analysis of the scope of section 16(b) in hostile takeovers).

64. See, e.g., Heublein, Inc. v. General Cinema Corp., 722 F.2d 29 (2d Cir. 1983) (exchange of stock pursuant to merger not a 16(b) sale), cert. denied, 465 U.S. 1066 (1984); Kay v. Scientex Corp., 719 F.2d 1009 (2d Cir. 1983) (overissuance of shares to insider was a 16(b) purchase); Rosen v. Drisler, 421 F. Supp. 1282 (S.D.N.Y. 1976) (exercise of stock options not 16(b) purchase).

Section 16(b) litigation arising since Kern County has been the subject of much scholarly debate. Commentators have proposed new or revised analyses to quell the confusion surrounding the statute, and judicial approaches to it. For example, see Tomlinson, supra note 24, at 953-56, proposing a single analysis for all transactions, whereby a court examines (1) whether there was a beneficial transfer for value, (2) whether the insider made an investment decision, and (3) the timing of the investment decision. Other commentators would focus on the insider's access to nonpublic information. See Note, Short-Swing Profits in Failed Takeover Bids-The Role of Section 16(b), 59 WASH. L. REv. 895, 905 (1984) [hereinafter cited as Note, Short-Swing Profits]:

The pragmatic approach that has evolved from Kern focuses on the form of the transaction. The voluntary form of the transaction creates section $16(\mathrm{~b})$ liability even though the statutory insider actually lacks access to inside information. This analysis results from a literal reading of the statute. Section 16(b) should not be literally applied, however, when such application would not further the statute's purposes. For example, section 16(b) should not apply when hostile takeover bidders have no access to inside information. An 
National Airlines ${ }^{65}$ and Pay Less Drug Stores v. Jewel Companies, Inc. 66

Texas International involved facts similar to Kern County. As in Kern County, the target company defeated the insider's takeover attempt by arranging a defensive merger. ${ }^{67}$ However, instead of simply waiting for the merger to exchange the target company's securities for the "white knight's" securities, the defendant, a ten percent beneficial owner, sold the target company's securities for cash prior to the merger. ${ }^{68}$ The United States Court of Appeals for the Fifth Circuit followed dicta in the Kern County decision ${ }^{69}$ and forced the insider to disgorge his profits. ${ }^{70}$

The court in Texas International held that because the transaction was voluntary, it did not fall within the "unorthodox transaction" category created by Kern County. ${ }^{71}$ The court therefore applied an "objective" analysis. ${ }^{72}$ The Fifth Circuit declined "to create an exception to the automatic 16(b) liability in cases where a defendant can prove that, notwithstanding its ownership of over $10 \%$ of the stock of the issuer, the

approach that is more consistent with the philosophy and goals of section 16(b) examines the position of the trader rather than the form of the transaction.

See also Note, Exceptions to Liability Under Section 16(b), supra note 5, at 1443-45 (proposing that noncontrolling beneficial owners be presumed not to have inside information).

65. 714 F.2d 533 (5th Cir. 1983), cert. denied, 465 U.S. 1052 (1984).

66. 579 F. Supp. 1396 (N.D. Cal. 1984).

67. Texas Int'l, 714 F.2d at 535 .

68. Id.

69. The Supreme Court stated that the hostile tender offeror in Kern County would have been liable for section 16(b) profits if it had sold its target's securities for cash prior to the merger. Kern County, 411 U.S. at 599-600.

70. Id. at 538-40; see supra note 59 and accompanying text.

71. Id. at 540. For a discussion of "voluntariness" in the context of Kern County's pragmatic analysis, see Note, Short-Swing Profits, supra note 64, at 900-01 (whether the insider controls the timing of the transaction determines "voluntariness"). Because the decision to sell the target company's securities prior to the merger exchange was entirely in the hands of Texas International, the transaction in this case could be considered voluntary.

72. Texas Int'l, 714 F.2d at 538-39.

The court described the pragmatic approach adopted in Kern County as "an extremely narrow exception to the objective standard of section 16(b)." Id. at 539. According to the court, transactions that do not receive "unorthodox" status are automatically subjected to objective analysis. Id. The court determined that even had the insider in Texas International been in an analogous position regarding the target-that is, a hostile position-"no valid basis for an exception to section 16(b) liability on these facts" would be stated. Id. The Fifth Circuit denied "unorthodox" status because the transaction consisted of a voluntary cash-for-stock sale, as distinguished from the involuntary exchange of shares pursuant to a merger that took place in Kern County. Id. at 539-40. Thus, the court applied an objective analysis. Id.

In contrast to the Texas International court, some courts have held that transactions that take place during a tender offer are necessarily unorthodox. See Pier 1 Imports of Georgia v. Wilson, 529 F. Supp. 239, 242-43 (N.D. Tex. 1981); Makofsky v. Ultra Dynamics Corp., 383 F. Supp. 631, 637 (S.D.N.Y. 1974); see also Block \& Barton, supra note 63, at 209 (listing these cases, and discussing Texas Int'l). 


\section{defendant had no access to inside information."73}

As already noted by commentators, the decision in Texas International was unfortunate. If the issuer and the tender offeror occupy hostile positions, there is no reason to believe that greater opportunity for speculative abuse exists where the offeror sells its securities prior to the merger, than where it waits to exchange its securities pursuant thereto. ${ }^{74}$ As in Kern County, Texas International was a "tender offeror, threatening to seize control of [the issuer], displace its management, and use the company for its own ends."75

A recent case reaches an opposite conclusion on the issue of whether a voluntary transaction can be "unorthodox."76 The transactions at issue in Pay Less Drug Stores v. Jewel Companies, Inc. ${ }^{77}$ emerged from Jewel's failed attempt to take over Pay Less Drug Stores. Pay Less sought to match Jewel's exercise of options to purchase Pay Less shares with Jewel's later sales of those same Pay Less shares. ${ }^{78}$

The court held that exercise of the options was an "unorthodox" transaction, ${ }^{79}$ recognizing that trading in options will often be unortho-

73. Texas Int $l, 714$ F.2d at 538 . One commentator has suggested that in examining tender offer transactions, courts should "allow the insider to prove that no improper speculation occurred" in those cases where the insider can rebut the presumption of access to insider information. The commentator argued that this defense be available to an insider regardless of whether the transaction was voluntary. See Note, Short-Swing Profits, supra note 64, at 905-06.

74. See Note, Short-Swing Profits, supra note 64, at 906 ("takeover bidder exchanging shares for stock within six months is arguably in the same position as the takeover bidder exchanging shares for cash"). This commentator has noted that there may be powerful financial reasons for a losing tender offeror to sell its shares of the target prior to the defensive merger. For example, the offeror may have borrowed considerable sums to finance the offer, and may therefore desire to repay the debt quickly to avoid interest payments. Id.

75. See Texas Int', 714 F.2d at 536; see supra note 56 and accompanying text.

76. Even though factually different than Texas International, Pay Less Drug Stores v. Jewel Cos., 579 F. Supp. 1396 (N.D. Cal. 1984), nonetheless stands for the proposition that the volitional character of a transaction does not automatically preclude "unorthodox" status. Id. at 1400-01. See infra notes 77-81 and accompanying text.

77. 579 F. Supp. 1396 (N.D. Cal. 1984).

78. Id. at 1399. Jewel bought the options from Pay Less shareholders with the understanding that they would not be exercised unless the Jewel tender offer failed. Id. at 1397. Jewel attempted to exercise its options to buy Pay Less shares on two separate occasions, but the Pay Less shareholders who had granted the options to purchase their shares refused to sell. Jewel successfully enforced its option contract in court. Id. at 1398. Actual purchase of these shares took place by court order, beyond the six months proscribed by section 16(b). Pay Less thus sought to match Jewel's sales of its stock with the attempted exercise of options to purchase Pay Less stock. Id.

Pay Less asserted four separate claims. In three, Jewel's alleged section 16(b) purchase consisted of one of the two attempts to exercise the option. In a fourth claim, Pay Less argued that Jewel "purchased" Pay Less shares when it made the decision to excrcise the options. The alleged sales consisted of either the involuntary sale occurring as part of the eventual cash-out merger, or Pay Less's voluntary sale of a block of shares prior to the cash-out merger. Id. at 1398-99.

79. Id. at 1399. 
dox ${ }^{80}$ More importantly, the Pay Less court held that a transaction may be "unorthodox," and thus subject to "pragmatic" analysis, even though the transaction is entirely voluntary. ${ }^{81}$ Thus, while Texas International tells insiders that the volitional nature of a transaction will distinguish "unorthodox" transactions from "garden variety" purchases and sales, ${ }^{82}$ Pay Less informs insiders that the vohitional character of a transaction should not prevent the transaction from receiving "unorthodox" status. ${ }^{83}$

Texas International and Pay Less present opposing judicial responses to application of section 16(b). This difference can be characterized as something more than a disagreement over what transactions the Supreme Court intended the term "unorthodox transaction" to include. The transactions from which section 16(b) litigation arises tend to be unusual or complex, or else result from contingencies that the statute seems unprepared to address. ${ }^{84}$ The Pay Less court, like the Max Factor, $L a m b$, and Kern County courts preceeding it, recognized that section 16(b) should not be applied where the substance and economics of a class of transactions do not present an opportunity for speculative abuse of inside information. ${ }^{85}$ In contrast, the Texas International court applied

80. Id. at 1400; see also supra note 40 and accompanying text.

81. Id. at 1400-01. The court stated:

While the majority opinion in Texas International stressed the fact that the defendant in that case had engaged in voluntary trades, in contrast with the involuntary conversion of shares that had occurred in Kern, this court believes that Kern should not be read to make volitional character of the transaction the sole inquiry in deciding whether a transaction is "unorthodox." The Supreme Court's opinion in Kern indicated that an analysis of the potential for speculative abuse should be made in cases involving "unorthodox" transactions. It did not limit the definition of unorthodox transactions to cases involving involuntary exchanges. Thus, this court concludes that the facts of the present case, despite the volitional nature of Jewel's attempted exercise of the option, present a sufficiently unorthoId. dox transaction to warrant the application of the Kern analysis.

The court in Pay Less recognized that the transaction at issue "hardly presents the 'orthodox" purchase-sale type of transaction that was involved in Texas International. In that case, the defendant had purchased shares on the open market pursuant to a tender offer, and later sold those shares . . . "Id. at 1400. Unlike Texas International, Payless involved options, and no shares changed hands. Id. at 1400 .

82. See supra notes $71-73$ and accompanying text.

83. See supra notes $79-81$ and accompanying text.

84. Cf. 3B H. BLOOMENTHAL, supra note 41, $\S 10.01$ [4] ("[T]here is a significant amount of litigation under section 16(b) suggesting that it often becomes a trap for the unwary."). Though occasionally the fault of counsel, it is also the "result of the possible application of the section to a number of situations which are not of the garden variety type."). Id.

85. A view that courts should be prepared to examine many types of unusual transactions, and not just those fitting within one set of criteria, seems to be presented in Kern County:

Under some broad language in [earlier] decisions, $\S 16(\mathrm{~b})$ is said to be applicable whether or not the transaction could possibly lend itself to the types of speculative abuse that the statute was designed to prevent. By far the greater weight and authority is to the effect that a pragmatic approach to $\S 16(\mathrm{~b})$ will best serve statutory goals.

Kern County Land Co. v. Occidental Petroleum Corp., 411 U.S. 582, 594 n.26 (1973). 
section 16(b) to a type of transaction that seemed to provide no such opportunity for abuse.

\section{Purchase and SAle of Convertible Debentures and UNDERLYING SECURITIES: THE NEED FOR AN ECONOMIC EQUIVALENCY TEST}

Gund v. First Florida Banks ${ }^{87}$ follows the lead of Texas International by mechanically applying section $16(\mathrm{~b})$ to a series of transactions that provide no opportunity for speculative abuse. ${ }^{88}$ This case represents a misapplication of the statute and highlights the need for courts to follow the underlying rationale of Max Factor, Lamb, Kern County, and Pay Less by refusing to find liability where the economics of a class of transactions eliminates the possibility of speculative abuse.

Gund involved a sale of convertible debentures and subsequent purchase of comnion stock within six months. ${ }^{89}$ The United States Court of Appeals for the Eleventh Circuit held the insider liable for 16(b) profits, despite the fact that the price of the debentures was fluctuating in relation to interest rates. ${ }^{90}$ The insider argued that if the market price of convertible securities is not fluctuating at levels implied by the conversion ratio, the two classes of securities should not be "matched" for $16(\mathrm{~b})$ purposes. ${ }^{91}$ That is, he contended that if the two classes of securities

86. See supra notes $65-75$ and accompanying text.

87. 726 F.2d 682 (11th Cir. 1984).

88. See infra notes $89-114$ and accompanying text.

89. Gund, 726 F.2d at $683-84$.

90. Id. at 687 . One other case has treated the issue of whether courts should match purchases or sales of convertible debentures with the underlying common stock. In Chemical Fund, Inc. v. Xerox Corp., [1964-1966 Transfer Binder] FED. SEC. L. REP. (CCH) 1 91,653 (W.D.N.Y. March 28, 1966), rev'd on other grounds, 377 F.2d 107 (2d Cir. 1967), the district court matched an insider's purchase of convertible debentures and sale of common stock. Id. at 91,418-19. In that case, unlike Gund, market prices of the two classes of securities were trading in relation to one another at their fixed conversion ratio. Id. at 91,418 . Thus, that case is entirely distinguishable from Gund; it is precisely the fact that the convertible debentures were not trading in relation to the common stock that allowed Gund to argue that he should have escaped section 16(b) liability. Gund, 726 F.2d at 685 .

91. Id. at 685. Gund argued that:

[T]he debentures were selling as fixed-price debt securities during the relevant period and that their price was influenced solely by fiuctuation in interest rates, with the conversion feature of the debentures rendered meaningless due to the drastic drop in the market price of the common stock. Gund argues that the factors which would affect common stock prices could therefore not affect debenture prices, and vice versa. Thus, Gund's sales and purchases were not "matching transactions" so as to give rise to the type of short swing Id. profits addressed by section $16(\mathrm{~b})$.

Professor Loss has stated that the "scant authority on the question of matching a purchase of one security with the sale of another is not conclusive." L. Loss, supra note 46 at 629 . He notes that where the two securities are economic equivalents, "it is desirable to match the purchase and sale for 
were not trading at prices implied by the conversion ratio, there was no opportunity for speculative abuse. ${ }^{92}$

The $6-7 / 8 \%$ convertible debentures and common stock were related in the following way. The debentures were issued in $\$ 1000$ denominations, and were convertible into 82.47 shares of common stock at a conversion price of $\$ 12-1 / 8$ per share. ${ }^{93}$ From 1971 to 1973, both securities "traded near the levels implied in their offering prices, i.e. the debentures sold for roughly their face value [\$1000] and the [common] stock traded in the neighborhood of $\$ 12 . " 94$ Beginning in 1974, the markets for both securities declined. By 1976, the convertible debentures were trading at only seventy-five percent of their issue price. ${ }^{95}$ The common stock, however, was sellimg at only fifty percent of its issue price. ${ }^{96}$ Thus, at this time the debentures were no longer trading at their fixed conversion ratio. ${ }^{97}$

Gund, a director of First Florida, ${ }^{98}$ had purchased $\$ 605,000$ in convertible debentures during 1972 and 1973. From July 1976 to March 1977, after the markets for the two classes of First Florida securities declined, Gund sold his entire debenture holdings. ${ }^{99}$ Gund purchased 77,000 shares of common stock with the proceeds of the debenture sales. Had Gund converted his debentures, instead of selling them, he would have received only 49,895 shares of common stock. ${ }^{100}$

The Eleventh Circuit held that section 16(b) hiterally applied to Gund's transactions, because, as an imsider, he sold and purchased the First Florida equity securities within a six month period. ${ }^{101}$ According

16(b) purposes." Id. at $628-29,653$ (specifically approving the matching of convertible debentures and common stock, as long as the securities are economic equivalents).

92. Gund, 726 F.2d at 686.

93. Id. at 684 .

94. Id.

95. Id.

96. $I d$.

97. Id. Normally, convertible debentures "considered by the market to be the substantial equivalent of the common stock . . . will rise in price with the common if the market price of the common, on adjustment for the conversion ratio, exceeds the call price for the debentures." L. Loss, supra note 46 , at 653 .

Conversely, where "conversion of debentures is not economical, it is their senior position and fixed interest claim that give them value." Id. For example, if Gund had converted his debentures to common stock, Gund would have received only $50 \%$ of the offering price of the securities. However, because bonds are interest-bearing instruments, the coupon rate placed a floor ou their price. Thus, at the time Gund sold his debentures, those securities were trading as "pure" bonds-that is, trading in relation to interest rates.

98. As a director, Gund was an "insider" for purposes of section 16(b). See supra note 3 and accompanying text.

99. Gund, 726 F.2d at 684.

100. Id. at $684-85$.

101. Id. at 687 . The court's analysis, in pertinent part, was as follows: 
to the Eleventh Circuit, if a transaction falls within the "literal language" of section 16(b), the courts may not examine the transaction to see whether there was a potential for speculative abuse. Thus, the court did not even have to reach the question of speculative abuse, since according to the court, no "unorthodox" transaction was involved. ${ }^{102}$

The underlying rationale of Blau v. Lamb $b^{103}$ would not allow the matching of a sale and purchase of convertible and underlying securities where the classes of securities involved were not trading at prices conforming to their fixed conversion ratio. ${ }^{104}$ Lamb demonstrated that where securities of the same issuer are economically equivalent-that is, where they trade at their conversion ratio-the conversion of one into the other does not change the insider's investment position, and should not be considered a purchase or sale under the statute. ${ }^{105}$ Logically, where the securities are economically equivalent, the sale of the convertible security and purchase of the underlying security is equivalent to the sale and purchase of the same security, and should be matched. ${ }^{106}$ Con-

\footnotetext{
Under [the] . . . "subjective" or "pragmatic" approach, an initial determination is made as to whether a transaction falls within the literal language of section 16(b). If an ambiguity is apparent, the inquiry becomes whether the transaction involved carries a potential for inside abuse. Only those transactions which are susceptible to abuse are found to be within statutory scope.

...

However, the law is clear that the pragmatic approach is to be used to determine the boundaries of section 16(b)'s definitional scope only in borderline situations, particularly Id. those involving unorthodox transactions.

102. Id. at 686-87. The Eleventh Circuit did not elaborate or define its conception of an "unorthodox" transaction. It merely stated that the "vast majority of cases in which the pragmatic approach has been followed involve involuntary transactions which are triggered by corporate reorganization." Id. at 686. The Supreme Court's language in Kern County is broader, however, referring to trading in warrants, options, and conversions as possible instances of "unorthodox" transactions. Kern County Land Co. v. Occidental Petroleum Corp., 411 U.S. 582, 593 n.24 (1973); see supra note 40 and accompanying text. The court in Pay Less Drug Stores v. Jewel Cos., 579 F. Supp. 1396, 1400-01 (N.D. Cal. 1984), argued that "unorthodox" transaction status is broad enough to include voluntary transactions. See supra notes 76-81 and accompanying text.

103. 363 F.2d 507 (2d Cir. 1966), cert. denied, 385 U.S. 1002 (1967).

104. See supra notes $26-44$ and accompanying text. This is essentially the situation presented in Chemical Fund, Inc. v. Xerox Corp., [1964-1966 Transfer Binder] FED. SEC. L. REP. (CCH) If 91,653 (W.D.N.Y. March 28, 1966), rev'd on other grounds, 377 F.2d 107 (2d Cir. 1967), discussed supra note 90.

105. See 3B H. BloomentHAL, supra note $41, \S 10.08$ ("The underlying basis for the approach of the Second Circuit is the fact that it views the [convertible and underlying securities] as [economic] equivalents.")

106. It is unlikely that insiders would often sell convertible debentures and purchase common stock when the securities are trading at their fixed conversion ratio. There is no investment rationale for such action. The insider would most likely avoid transaction costs and convert the securities. However, an insider might sell the debentures and later purchase stock in order to recognize a loss for tax purposes, or in order to solve immediate cash flow problems. Thus, there remains the possibility that, even when the securities are economically equivalent, an insider may engage in transactions similar to those which took place in Gund.
} 
versely, where the securities are not economically equivalent, sale of the convertible security and purchase of the underlying security is not the same, in the eyes of the insider or the investing public, and should not be matched. ${ }^{107}$

At the time of Gund's transactions, the First Florida convertible debentures were trading at seventy-five percent of their issue price, while the common stock traded at only fifty percent of its issue price. The securities matched in Gund were thus not economically equivalent. Sales of convertible debentures and purchases of common stock were not the same as sales and purchases of the same securities. Such transactions, when examined under the rationale of $L a m b$, should escape liablity. ${ }^{108}$ Any First Florida security holder with a portfolio of debentures and a goal of increasing ownership of the corporation would have sold debentures and bought common stock rather than convert. Inside information was not necessary to arrive at such a strategy. ${ }^{109}$

107. See L. Loss, supra note 46 , at $653-54$ (where conversion of debentures into stock is not economical, debentures are not the same class of security as the stock, and should not be matched with the stock).

108. This proposal raises an interesting point regarding Rule 16b-9(a). Rule 16b-9(a) provides a safe harbor for conversion transactions. See supra note 44. The rule did not incorporate an economic equivalency test. As the Eleventh Circuit noted, Gund is excluded from using this safe harbor because he did not convert his debentures into common stock, but instead sold debentures and bought common stock. Gund v. First Florida Banks, 726 F.2d 682, 687, 687 n.7 (11th Cir. 1984). There is, however, no language in Rule 16b-9(a) stating that the safe harbor it provides is exclusive. The court was thus not bound by the rule to force Gund to disgorge profits. The rule does not in any way prohibit the use of an economic equivalency test as proposed by this note.

109. In other words, inside information was almost certainly not the motivation for the the Gund transactions. An investor would need only an elementary understanding of mathematics to determine that converting debentures in this situation would produce fewer common stock shares than selling his debentures and purchasing common stock.

Several cases have already stated that when inside information can in no way motivate a series of purchases and sales, insiders are not subject to section 16(b) liability. See Merrill Lynch, Pierce, Fenner \& Smith, Inc., v. Livingston, 566 F.2d 1119, 1121 (9th Cir. 1978); Heublein, Inc. v. General Cinema Corp., 559 F. Supp. 692, 704 (S.D.N.Y. 1983), affd, 722 F.2d 29 (2d Cir. 1983), cert. denied, 465 U.S. 1066 (1984). These courts argued that, if the information known to the insiders could not lead to an investment decision, speculative abuse could not result. Furthermore these courts argued that 16(b) liability should not attach if there is no opportunity for speculative abuse. Similarly, speculative abuse in Gund was not a concern because the very economics of the transaction made inside information irrelevant.

In Heublein, no formal tender offer was made. Instead, the issuer engaged in a merger, prior to any tender offer, to rid itself of an "unwelcome investor," General Cinema Corporation. Heublein, 559 F. Supp. at 702. General Cinema had been buying shares of the issuer to a point where it eventually held $18.9 \%$ of the total number of outstanding shares. At the time when General Cinema reached a $16.2 \%$ ownership level, the issuer engaged in negotiations for an "asset swap" with General Cinema, in order to persuade General Cinema to discontinue buying the issuer's shares. Id. at 694. During these negotiations the issuer disclosed to General Cinema nonpublic information which the issuer concedes was "nonmaterial" under federal securities laws-information which could not be speculatively exploited for section 16(b) purposes. Id. at 704. The court held that, under Kern 
Because the Gund court determined that section 16(b) applied literally to the transaction, it stated that the court was precluded from examining the substance and economics of the transactions to determine whether there was potential for speculative abuse. ${ }^{110}$ In other words, the court equated the Gund transaction with the most basic section 16(b) violation: the purchase and sale of stock on the market within six months. An argument can be made, however, that the provision does not apply to the sale of convertible debentures and purchase of common stock so clearly as to preclude any further examination.

Under section 3(a)(11) of the Act, "equity security" includes "any stock or similar security or any security convertible . . . into such security."111 Convertible debentures are thus equity securities for purposes of section 16(b) only because of their conversion feature. Without a conversion feature, purchases and sales of debentures or any other debt securities could not be matched with purchases and sales of common stock to form section 16(b) violations. Convertible preferred stock, by contrast, is not dependent upon its conversion feature to be matched with common stock to form section $16(\mathrm{~b})$ violations. Convertible preferred stock is an equity security under section $3(a)(11)$ because it is "stock or [a] similar security. ..."

The Gund court might have looked to the worthlessness of the debentures' conversion feature, and questioned whether, for purposes of Gund's transactions, the convertible debentures were equity securities. ${ }^{112}$

County, an unorthodox transaction was stated. Further, it held that nonmaterial inside information does not present an opportunity for speculative abuse. Id. at 703-05.

110. See supra notes 101-02 and accompanying text.

111. 15 U.S.C. $\$ 78(\mathrm{a})(11)$ (1982) (emphasis added).

112. Though the language of section $3(a)(11)$ is broad in defining any convertible security as an equity security, it would not be unreasonable to read the language as implying that in order to be an equity security, the conversion feature must have value.

The legislative history of section 3(a)(11) does not address this point. Instead, it emphasizes merely that the definition of equity security was intended to include any securities of a speculative nature. Thus, for example, long term, interest-bearing bonds were excluded from the definition. See Hearings on Stock Exchange Practices Before the Senate Comm. on Banking and Currency on S. Res. 84, 73d Cong., 1st Sess. 7541-43 (1934). In those hearings, the Senate Committee considered a provision to section 3(a)(11) that would have removed any "preferred or guaranteed stock which is entitled to receive only a fixed or limited dividend," from the definition of equity security. Id. at 7541. In the debate that followed, an attorney for the New York Stock Exchange attempted to convince the senators that such securities do not pose speculative risks. This provision was not included in the final definition of section 3(a)(11). See supra note 16.

The committee did not examine the issue raised by the conversion feature of convertible debt instruments or the speculative risks associated with such securities. Arguably, where the conversion feature is worthless, convertible debentures pose no greater speeulative risks than do nonconvertible debentures. But see Armour \& Co., [1970-1971 Transfer Binder] FED. SEC. L. REP. (CCH) \ 78,025 (convertible debentures are equity securities of corporation into whose underlying securities they are convertible; no discussion whether conversion feature has value). 
The First Florida common stock was so greatly devalued that the price of the debentures fluctuated solely with the interest rates. In this environment, converting the debentures produced fewer common stock shares than simply selling debentures and purchasing common stock on the market. Indeed, only an insider, because of potential section $16(\mathrm{~b})$ liability, would even consider converting his securities.

There appears to be only one scenario in which Gund could have used inside information to guide and profit from his transactions. Perhaps Gund had information that the common stock, which was even more devalued than the convertible debentures, would soon increase in price relative to the debentures. ${ }^{113}$ Trading on this information, he conld have rearranged his portfolio to maximize his common stock holdings. Thus, instead of converting the debentures to common stock, he sold the debentures and purchased the common stock on the open market. If the common stock price then increased, he would profit from these transactions.

In this scenario, Gund's profits from the use of inside information would come from a subsequent sale of the common stock matched with the purchase of the common stock. Yet these are not the profits the Eleventh Circuit forced Gund to disgorge. Gund was held hable for profits resultimg from the sales of debentures and the purchases of cominon stock. ${ }^{114}$ The fact that he sold the convertible debentures in order to generate the capital to purchase the common stock should not inatter. The capital could just as easily have coine from another source. In effect,

113. After a sufficient price increase in the common stock, to the point where the common stock approached $75 \%$ of its issue price, the debentures would again begin to trade in relation to the common stock. However, there is no reason to expect that the debentures would trade in relation to the common stock at any time before the common stock approached $75 \%$ of its issue price. The common stock could thus increase in price relative to the debentures, from $50 \%$ to $75 \%$ of its issue price, without a proportionate increase in the price of the debentures.

114. The Eleventh Circuit upheld the district court's computation of the profits to be disgorged. Gund, 726 F.2d at 687-88. The district court used the computation method suggested by Rule 16b6, 17 C.F.R. $\$ 240.16 \mathrm{~b}-6$ (1985). That rule matches actual sale prices of the underlying security with the lowest market price of the underlying security occurring within six months of the sale. Rule 16b6 was intended to measure profits resulting from an exercise of stock options, matched with the later sales of the underlying securities. The district court used this method by analogy, and matched the actual purchase price of the common stock with the highest inarket price of the common stock occurring within,six months of the sale of the debentures. Gund, 726 F.2d at 687.

The Eleventh Circuit stated that "were we writing on a clean slate," it would employ the computation method developed by Smolowe v. Delendo Corp., 136 F.2d 231 (2d Cir.), cert. denied, 320 U.S. 751 (1943). Gund, 726 F.2d at 687-688. The Smolowe method involves inatching the highest sale price received by the insider for the issuer's equity securities with the lowest purchase price paid by the insider for the issuer's equity securities within a given six month period. See generally Comment, supra note 61 at 865-67 (explaining Smolowe, and discussing modern problems arising from application of the method to option transactions). 
the Gund court punished an insider for profits he may or may not have made on transactions other than the ones at issue.

\section{CONCLUSION}

The Eleventh Circuit reached an incorrect result in Gund v. First Florida Banks. The holdings in Blau v. Max Factor \& Co. and Blau v. $L a m b^{115}$ - that conversions of economically equivalent securities are not sales or purchases for the purposes of section 16(b) - support this conclusion. The two classes of securities in Gund were not economically equivalent. In this situation, the rationale for treating convertible debentures as equity securities for the purposes of section 16(b) does not apply. Thus, where convertible debentures and underlying securities are being traded independently, sales and purchases of the convertible and underlying securities should not be matched. 116

Daniel B. Bogart

115. See supra notes $36-40$.

116. One last example of section 16(b)'s operational dysfunction may help demonstrate the illogic of holding Gund liable for his transaction. Gund was forced to disgorge profits that resulted from selling convertible securities, and buying underlying securities, even though the two classes of securities were trading independently. Under present law, however, it is conceivable that courts would not match the sale of warrants and the purchase of common stock, even though the two classes of securities invariably trade in relation to each other.

This result may occur because courts have matched the exercise of warrants with the sale of common stock. See Morales v. Mapco, Inc., 541 F.2d 233, 235-36 (10th Cir. 1976), cert. denied sub nom. Ross v. Morales, 429 U.S. 1053 (1977). The Mapco court reasoned that, because warrants require a fixed exercise price and do not give its owner an equity position in the issuer, warrants and common stock are not economically equivalent securities. Id. at 236. However, the sale of warrants and purchase of common stock would provide an opportunity for speculative abuse because the classes of securities trade together. This transaction would be equivalent to buying and selling common stock. The better result would be to match the purchase and sale of these two classes of securities. Cf. Tomlinson, supra note 24 , at $959-60$ (suggesting that "acquisition of the option is acquisition of beneficial ownership of the underlying stock," and arguing that a sale of stock within six months should be matched with a purchase of an option). It would be inconsistent to hold Gund liable on a transaction that presented no opportunity for speculative abuse, when other transactions that do present such an opportunity may escape liability. 